\title{
REMEMBERING NYERERE: POLITICAL RHETORIC AND DISSENT IN CONTEMPORARY TANZANIA
}

\author{
FELICITAS BECKER*
}

\begin{abstract}
This article examines the changing uses of political rhetoric around the burial of Julius Nyerere in 1999. It argues that the ruling party uses rhetoric as a means of 'soft power', but also documents how this rhetoric, though geared towards legitimizing Nyerere's successors, employed tropes that were rejected by some people and were used by others to critique leaders who were perceived to lack the selfless integrity attributed to Nyerere. The article compares funerary songs by a government-sponsored band, popular at the time of Nyerere's death, with memories of Nyerere in rural areas in the early to mid-2000s. While the image of Nyerere in the funeral songs as a benign family patriarch writ large still persists, it coexists with strongly divergent constructions of Nyerere as an authoritarian ruler or a self-seeking profiteer. Moreover, the 'official', benign Nyerere has been employed not only by government and party faithful, but also by striking workers, opposition politicians, and critical newspapers as a measure of the shortcomings of his successors. The invocation of Nyerere as a paragon of an endangered ideal of virtue in public office indicates widespread anxieties towards a state that often disappoints but occasionally delivers, in unpredictable turns, and the limits of the government's ability to shut down dissent.
\end{abstract}

THIS ARTICLE IS AN EXAMINATION of the views and attitudes expressed around the death in 1999 of Tanzania's first President, Julius Nyerere, and the memories of Nyerere in rural areas in the early to mid-2000s. It draws on interviews, informal conversations, and newspapers from the thirteen years since his death to analyse two phenomena. ${ }^{1}$ One is the promotion by officials, and by state and private media, of a particular

\footnotetext{
${ }^{\star}$ Felicitas Becker (fmb@cam.ac.uk) is in the History Faculty, University of Cambridge. I would like to thank Rita Abrahamsen, Nic Cheeseman, Carola Lentz, John Lonsdale, Megan Vaughan, and two anonymous reviewers for helpful comments on the article, Jim Giblin for pointing me towards MwanaHalisi and Raia Mwena and providing a copy of the cartoon, and Zuhura Mohamed for research assistance. Thanks also to the EU FP7 programme for the Marie Curie career integration grant No. 303556 that supported the research.

1. The five interviews referred to in more detail below form part of a collection of about 400 interviews, many of which mentioned Nyerere in passing. I chose this subset because it dealt most explicitly with Nyerere's policies as President.
} 
interpretation of Nyerere's life and legacy. Tanzania's ruling 'Party of the Revolution' or Chama Cha Mapinduzi (CCM) made a well-prepared attempt to claim his memory before his body had even returned to the country from the London hospital where he had sought treatment for his final illness. The focus of the official presentation of the former President is summarized in the title of one of the commemorative songs which a CCM-sponsored band put out as soon as his death was announced: Lulu ya amani, 'The pearl of peace'. During the weeks after Nyerere's death, the heritage of peaceful societal relations that he was said to have bestowed on Tanzania - and of which the CCM claims to be the enduring guarantor - became the focus of a sustained media campaign characterized by discreet cooperation between state and non-state actors. ${ }^{2}$ The ruling party has consistently returned to this vision ever since.

The second focus of this article is the limited reach and varied uses of this rhetoric, and what it can tell us about the dynamics of state-society relations in Tanzania. ${ }^{3}$ Its use by CCM may appear an obvious political ritual, merely affirming the party's rarely challenged dominance. The following pages, though, start from the proposition that notwithstanding this dominance, agents of the Tanzanian government manage their state's relative weakness partly by actively seeking and building consensus among the governed. The governed, conversely, produce interpretations of Tanzania's politics that diverge significantly from official ones. In particular, they evoke Nyerere as the embodiment of civic virtue in public office to criticize the perceived lack of the same qualities in his successors.

Thus some observers were openly dismissive of the benign patriarchal role attributed to Nyerere in many official and private statements at the

2. Press coverage of Nyerere during the month following his death is assembled at <http:// www.juliusnyerere.info/index.php/resources/news/press_coverage_from_the_internet_on_ nyereres_death/> (11 December 2012). Although this website is clearly pro-Nyerere and so is much of the press coverage, it includes some critical comment, mainly from abroad (for an example, see the obituary from The Economist).

3. One telling aspect of these media images that cannot be fully discussed here for reasons of space is the religious language deployed, which arguably was carefully tailored to sidestep religious tensions in Tanzania at the time, both within Catholicism (Nyerere's affiliation) and between Christians and Muslims. Islamist criticism of Nyerere merits its own article and is not included here. On religion in Tanzanian politics, see David Westerlund, Ujamaa na Dini: A study of some aspects of society and religion in Tanzania, 1961-1977 (Nordiska Afrikainstitutet, Stockholm, 1980); on invective against Nyerere as anti-Muslim see Mohamed Said, The Life and Times of Abdulwaheed Sykes (1924-68): The untold story of the Muslim struggle against British Colonialism in Tanganyika (Minerva Press, London, 1998); on his role in the Zanzibari revolution, execrated by Islamists, see Sauda Sheikh Barwani et al., Unser Leben vor der Revolution und Danach: Maisha yetu kabla ya mapinduzi na baadaye (Rüdiger Köppe Verlag, Köln, 2003); on tensions among Tanzanian Catholics that extended into Nyerere's family, see Panafrican News Agency, 'Nyerere's daughter denied holy communion', 20 October 1999, <http://allafrica.com/stories/199910200075.html> (12 December 2012). 
time, and even where observers operated within the frame of reference set by official rhetoric, there were tensions within and between official and popular views of Nyerere's legacy. At first sight, the notion of Nyerere as the founder of a peaceful, consciously non-violent polity appears to sit quite well with another description of him that quickly became ubiquitous in Dar es Salaam during the preparations for his funeral, and has persisted since: Nyerere the mbabe wa wanyonge, the 'champion of the downtrodden' (wanyonge denotes both monetary poverty and a lack of social status and connections; mbabe is 'lord, strong patron, strongman'). This memory is easily derived from the notion of Nyerere as a family patriarch writ large.

Nevertheless, the two descriptions of Nyerere have potentially conflicting implications. For CCM officialdom, the invocation of Nyerere as the champion of peace serves as a potential legitimization for crackdowns on dissent: the message is 'Don't rock the boat; do not squander Nyerere's peaceful heritage'. Conversely, the notion of Nyerere the champion of the downtrodden can also be used to legitimize dissent against perceived social injustice, allowing non-elite citizens to invoke Nyerere against CCM grandees.

Official efforts to exploit Nyerere for consensus building show an arguably under-studied facet of politics in Africa at large, and Tanzania in particular: the use of persuasion, and more specifically, of relatively discreet persuasion, by politicians. Persuasion, or the use of rhetoric, amplified through mass media, by government representatives or sympathizers to create broad-based consensus, is recognized as a core element of politics in states where elections decide political fortunes. ${ }^{4}$ Given the autocratic nature of many postcolonial political regimes in Africa, it has been less frequently explored in this context; the focus has instead been on political networks and patronage. ${ }^{5}$ Where persuasion is recognized as a factor in African politics, most often in the form of 'performative' politics, it is often heavy-handed, and geared towards the political advantage or survival of individual autocratic rulers: Mobutu's self-styling or the celebrations surrounding Robert Mugabe come to mind. ${ }^{6}$ Funerals have also been known to be manipulated in this way. ${ }^{7}$

4. See Michael D. Cobb and James E. Kuklinski, 'Changing minds: political arguments and political persuasion', American fournal of Political Science 41, 1 (1997), pp. 88-121; Richard Perloff, The Dynamics of Persuasion: Communication and attitudes in the twenty-first century (Taylor and Francis, London, 2003).

5. For example, see Jean-François Bayart, The State in Africa (Longman, London, 1993); Robert Jackson and Carl Rosberg, Personal Rule in Black Africa (University of California Press, Berkeley, CA, 1982).

6. For a general characterization of this style of politics, see Jean-François Bayart, 'Africa and the world: a history of extraversion', African Affairs 99, 395 (2000), pp. 217-67. For a careful examination of a more collectivist, but still strongly hierarchical, form of political theatre in an East African context, see Angelique Haugerud, The Culture of Politics in Modern Kenya (Cambridge University Press, Cambridge, 1993).

7. Florence Bernault, 'Colonial bones: the 2006 burial of Savorgnan de Brazza', African Affairs 109, 436 (2010), pp. 369-90. 
Tanzania was undeniably autocratic for much of its post-colonial history, governed between 1964 and 1992 by a one-party state that deployed widespread coercion in its rural resettlement campaign ('villagization') and attempted transition to 'African socialism' (ujamaa) between 1968 and about 1986. Following the official end of this phase of state interventionism, observers have attributed the resilience of social order during the era of political liberalization and structural adjustment predominantly to non-state actors. ${ }^{8}$ Given this, and the fact that the CCM has remained dominant despite the reintroduction of multipartyism, one might think that the government does not have much work to do to create consensus.

The present discussion, by contrast, takes cues from Catherine Boone's insistence that post-colonial African governments have actively to manage relations with local, often informal power brokers, and with wider publics. ${ }^{9}$ Boone demonstrates that the same government may use very diverse strategies in different regions. Arguably, similar variations can occur over time and between contexts, as well as over space. Taking off from this insight, this article examines the different ways that Nyerere's memory has been constructed as a case study of the way that political persuasion has been used in Tanzania alongside more authoritarian methods of political control. In a sense, ruling politicians' persistent invocation of Nyerere's legacy indicates that despite the relative quiescence of Tanzanian politics, they do not take their audience for granted. ${ }^{10}$

At the same time, the failure of the 'official' version of Nyerere to dominate the conversation exclusively offers openings to trace political attitudes among 'non-elite' Tanzanians. This description covers a very diverse population, in which the levels of marginality are very finely graded. This article focuses on an aspect of popular political discourse that is salient across this spectrum: the tendency to deplore the decline of civic virtue in public office from the end of Nyerere's reign onwards, while reaffirming the essential role of the state in society, above all in the interest of the weak.

With pronounced moralist overtones, this way of pressing claims on the state can sound naïve and anachronistic. In this regard it resonates with

8. Aili Mari Tripp, Changing the Rules: The politics of liberalisation and the urban economy in Tanzania (University of California Press, Berkeley, 1997); Bruce Heilman and Paul Kaiser, 'Religion, identity and politics in Tanzania', Third World Quarterly 23, 4 (2002), pp. 691709. An increase in social and political conflict has been warned of repeatedly, but so far has not been realized: Paul Kaiser, 'Structural adjustment and the fragile nation', Fournal of Modern African Studies 34, 2 (1996), pp. 227-37.

9. Catherine Boone, Political Topographies of the African State: Territorial authority and institutional choice (Cambridge University Press, Cambridge, 2004).

10. This is not to suggest that there was no dissension within CCM and government. For factionalism in the 1980s and 1990s, see Tripp, Changing the Rules, Chapter 4. 
the proposition, made most explicitly by Goran Hyden, that pre-capitalist ('pre-modern') forms of political and economic reasoning coexist with the formal ('modern') institutions of government in Tanzania and shape their actions. ${ }^{11}$ There are two competing uses of the positive image of Nyerere at work here: he is either a patriarchal precursor validating the current government, or a paragon of public virtue highlighting the shortcomings of his successors. In as much as both of these uses implicitly affirm Nyerere as a benign patriarchal figure they resonate with the concept of 'economy of affection' that Hyden employed to summarize his understanding of Tanzanian society as being predominantly 'pre-capitalist' and organized according to an informal moral economy. ${ }^{12}$

Closer examination of the rhetoric around Nyerere, however, shows that rather than being a mere holdover from a more communal past, the moral and familial terms described here are partly a product of the sphere of formal government, and of its efforts to accommodate international policy prescriptions with their emphasis on 'good governance'. They also reflect Tanzanians' concrete present-day experience of a state that often disappoints but occasionally delivers, in unpredictable turns, and to which anyway there is no alternative. In this regard, the present study elaborates on James Giblin's insistence that the 'idiom of kinship' has always been political and has come to be used in post-colonial Tanzania to critique those in power. ${ }^{13}$ In line with Priya Lal's recent re-examination of villagization, it finds a polyphony of elaborations on the official terms of politics produced by people marginal to the making of policy. ${ }^{14}$ In consequence, it also shows that the use of 'big-man' imagery in African politics does not always succeed in dampening down dissent. ${ }^{15}$

\section{The 'official' Nyerere and his observers}

Julius Nyerere left Tanzania in early September 1999 to seek treatment at St Thomas's hospital in London for leukaemia or, as Tanzanian media put it, kansa ya damu (cancer of the blood). He died in this hospital on 14 October. His body was repatriated to Tanzania and lay in state in a

11. Goran Hyden, Beyond Ujamaa in Tanzania: Underdevelopment and an uncaptured peasantry (University of California Press, Berkeley, CA, 1981).

12. Hyden's 'economy of affection' is a kindred spirit of the 'moral ethnicity' described in Bruce Berman and John Lonsdale, Unhappy Valley: Conflict in Kenya and Africa (James Currey, Oxford, 1992), Volume 2, chapters 11-12.

13. James Giblin, A History of the Excluded: Making family a refuge from state in twentiethcentury Tanzania (James Currey, Oxford, 2006).

14. Priya Lal, 'Self-reliance and the state: the multiple meanings of development in early post-colonial Tanzania', Africa 82, 2 (2012), pp. 212-34.

15. Here Tanzania appears to differ from the DRC; compare with Michael Schatzberg, Political Legitimacy in Middle Africa: Father, family, food (Indiana University Press, Bloomington, IN, 2001). 
coffin with a plexi-glass window. Tanzanians queued up for hours for the opportunity to walk past. Subsequently, the body was taken to Nyerere's home village of Butiama in the Lake Victoria region for burial. During his illness his health had been a regular topic on national news. His death was announced in a speech by his successor Benjamin Mkapa, much repeated over the following days. It set the tone for the heavy focus on unity in the official interpretation of Nyerere, with Mkapa imploring his fellow citizens to believe that the foundation of unity the deceased had laid was strong enough to hold beyond his death. ${ }^{16}$

Led by the Prime Minister, and making use of the country's interventionist media laws, the government also declared a period of national mourning and suspended regular broadcasting. ${ }^{17}$ The state TV channel switched to a solid diet of Nyerere footage, partly taken from his life, and partly from the ongoing funerary process. Private broadcasters followed the lead: one of them covered a live 'wake' held by the popular musician Remmy Ongala. Sitting on the floor of a darkened room in what was presumably his own home, in a shirt and loincloth with his legs outstretched before him, Remmy gently shook his dreadlocked head and hummed a tune. ${ }^{18}$ In this way he exactly recreated the subdued atmosphere of a house in mourning. By most standards, this was poor TV, but clearly the Tanzanian broadcaster felt it worked, as Ongala's wake was broadcast for days. $^{19}$

Meanwhile the popular CCM-backed band, Tanzania One Theatre (TOT), led by the singer Captain Komba, produced three funeral songs, audiotapes of which appeared on the streets in apparently unlimited numbers within hours of the death being announced. ${ }^{20}$ The same tunes came from every one of the wooden carts selling music on street corners. One of these songs was 'Pearl of peace'; the others were entitled Buriani Mwalimu, 'Rest in peace, Teacher', and Awamu ya kwanza, 'The first era'. During the weeks following Nyerere's death, the obituary songs by

16. Benjamin Mkapa, 'Presidential address', 15 October 1999, <http://news.bbc.co.uk/2/ hi/africa/474919.stm> (17 December 2012).

17. On media law, see Kelly Askew and John Francis Kitime, 'Popular music censorship in Tanzania', in Michael Drewett and Martin Cloonan (eds), Popular Music Censorship in Africa (Ashgate, London, 2006), and Martin Sturmer, The Media History of Tanzania (Ndanda Mission Press, Ndanda,1998).

18. On public perceptions of Remmy Ongala, see Werner Graebner, 'Whose music? The songs of Remmy Ongala and Orchestra Super Matimila', Popular Music 8, 3 (1989), pp. 243-58.

19. Remmy Ongala, who died in the late 2000s, was, at least until his conversion to bornagain Christianity around 2004, a very popular figure who gave his name to a daladala route taxi stop in his neighbourhood, Sinza ('kwa Remmy').

20. For the intricate personal and professional connections between TOT, Captain Komba, and CCM, see Laura Edmondson, Performance and Politics in Tanzania: The nation on stage (Indiana University Press, Bloomington, IN, 2007). 
Captain Komba and TOT became by far the most salient commentary on the meanings of Nyerere's life and death. They deserve to be quoted at length.

\section{Buriani Mwalimu}

Ndugu Watanzania

Sasa yametimia

Yamealikwa na mwenyezi Mungu

Aliye[inaudible] na kipenzi ya

watu

Mwalimu Nyerere sasa ametuaga

Ndugu Watanzania

Tumebaki yatima

Ndugu Watanzania

Sasa tufanye nini

Tudumishe amani

Aliyeyogombania

Nguzo wa umoja na utulivu

Dunia haitakusahau daima
'Rest in peace, Teacher'

Fellow Tanzanians

Now it has come to pass

It has been ordained by the almighty God

He who [inaudible] and the love of the people

Teacher Nyerere has bid us goodbye

Fellow Tanzanians

We have remained behind as orphans

Fellow Tanzanians

Now what shall we do?

Let us perpetuate the peace

That he [Nyerere] fought for

Pillar of unity and calm

The world will never forget you

This song was the one most widely heard during the weeks after Nyerere's death. In keeping with common ways of speaking about death, it evokes God's will before Nyerere has even been mentioned by name. It also brackets Nyerere the guarantor of peace with Nyerere the patriarch, the quasi-parent (whose death 'orphans' Tanzanians).

Leo tunaagana na rafiki yetu

Mwenzetu, ndugu yetu

Mwalimu Nyerere

Taifa linahuzunika

Afrika yahuzunika

Dunia yahuzunika

Pamoja twasema kwa heri

Kwa heri mwalimu ...

Sasa tuende wapi tukapate

ushauri ...

Ulitutoka wakati twakuhitaji ...

Eee, Mungu umpokee mtumishi wako
Today we say goodbye to our friend

One of ours, our relative

Teacher Nyerere

The country is saddened

Africa is saddened

The world is saddened

Together we say goodbye

Goodbye teacher...

Now where shall we go for advice...

You left us at a time when we needed you ... Eee, God receive your servant

Again, Nyerere is spoken of as a family member and elder: a source of advice. Moreover, the transition from 'the country' to 'the world' 
emphasizes his global standing, suggesting that even in death he had the ability to turn the eyes of the world upon Tanzania.

\section{Lulu ya amani}

Lulu ya zamani ya amani Imejificha wapi tutafute

Lulu ya zamani ya upendo Imejificha wapi tutafute

Amani imetoweka Afrika Amani imetoweka dunia

Tanzania imejichimbia
'The pearl of peace'

The pearl of old of peace

Where has it hidden itself, let us search

The pearl of old of love

Where has it hidden itself, let us search

Peace has disappeared from Africa

Peace has disappeared from the world

In Tanzania it has made itself at home.

Here, Tanzania is set in a global comparison and its political stability identified as an asset any nation would cherish. Although this 'peace' is not explicitly attributed to Nyerere's good works, the association of the song with the rest of the audiotape's content drives home the point: Nyerere has bequeathed peace to Tanzania, which is a source of national pride.

The songs were very carefully tailored to popular tastes. They were an exact rendering of the musical style known in Tanzania as ' $k w a y a$ ' from the English word 'choir': the soloist's voice is answered by a women's choir in close harmony. The origins of this style lie in church music, but it was among the first to become widely available commercially. It is very 'local' to Tanzanians, but does not fit clearly into a roster of traditional vs modern.

The songs also persistently position Nyerere as a 'man of the people' 'one of us', a relative and friend, whose death affects all Tanzanians personally as well as collectively. At the same time, and without any apparent sense of contradiction, they elevate Nyerere to a heroic and indeed saintly status: he has 'gained us respect', he is 'a pillar of unity and peace' a source of advice as well as pride, and a servant of God. ${ }^{21}$ Together, these songs are strong evidence of the CCM leadership's concern to transform Nyerere into a source of civic pride and, above all, restfulness; of consensus with their own stewardship of his political heritage. ${ }^{22}$

21. An explicit campaign to have Nyerere declared a saint has reportedly been under way since 2006. See The New Sudan Vision, 'Tanzania: Nyerere fit to be a saint - Museveni', 2 June 2009, <http://www.newsudanvision.com/index.php?option=com_content\&view=article\& id=1717:tanzania-nyerere-fit-to-be-a-saint-museveni\&catid=9:arts-and-culture\&Itemid=22> (23 August 2011).

22. For CCM's concerted efforts to assert control over TOT, see Edmonton, Performance and Politics. 
Most of the Tanzanians I interacted with in 1999 received this message positively, while also elaborating it beyond official meanings. At the time, I lived in a household in central Dar es Salaam that contained five adults. The household head was a medical doctor, while the other grown-ups had varying levels of secondary education. Too cloistered for their own liking, they treated the former President as a legitimate topic for conversations between chores. During his illness they asked questions such as what exactly was blood cancer? Did he have any chance of survival? How come the symptoms of his drawn-out illness, according to some rumours, so much resembled those of AIDS? How were his children coping? Much of this was ordinary gossip, with a hint of extra drama added by the political and moral authority of the dying man. It confirmed Nyerere's importance while also humanizing and banalizing him.

Together, the carefully put-together TV content and the way it was integrated into everyday conversation had the effect of both enshrining Nyerere's death as a singular national event, and making it intelligible in the same terms as the death of a neighbourhood notable. Perhaps the most banal element in the media campaign, but also one that was very effective in showing how widely the death was noted, was the Nyerere kanga cloth: in the national colours, with a smiling portrait of Nyerere surrounded by the dates of his birth and death. As a women's dress, it became very visible for the remainder of the year. In quite a concrete way, Tanzanians 'owned' Nyerere's death.

An element of careful planning is evident in the prompt production of 'themed merchandise' (audiotapes and kangas), as well as the funerary ceremonies and their broadcasting. It succeeded in minimizing any sense of crisis and aided in spreading a particular understanding of Nyerere, characterized by the equation of national politics with the small-scale, personal interactions characteristic of families and neighbourhoods. ${ }^{23}$ International journalists commented on the genuine grief shown by many 'ordinary' Tanzanians. ${ }^{24}$ However, the people capable of getting to the queue to see Nyerere's coffin, or of accessing Internet forums to express

23. In a sense, this is the opposite of the colonization of formal institutions by informal, often kin-based networks that observers of African politics often comment on: a politician who, by all accounts, kept politics and personal relationships separate, was reinvented as everyone's family member. For the personalization of African politics, see Patrick Chabal and Jean-Pascal Daloz, Africa Works: Disorder as a political instrument (Indiana University Press, Bloomington, IN, 1999); Bayart, The State in Africa.

24. The Times (London), 'Thousands flock to see Nyerere's coffin', p. 49, 19 October 1999, <http://www.juliusnyerere.info/images/uploads/nyerere_press_coverage_1999.pdf> (23 August 2011); The Independent, 'Tanzania weeps for father of the nation', p. 52, 20 October 1999, <http://www.juliusnyerere.info/images/uploads/nyerere_press_covarage_1999.pdf> (23 August 2011). For overwhelmingly positive views on Nyerere from East Africa, see $B B C$ Online, 'Email tribute', p. 40, 18 October 1999, <http://www.juliusnyerere.info/images/ uploads/nyerere_press_covarage_1999.pdf> (23 August 2011). 
their sense of loss, were not quite 'ordinary', as few Tanzanians at the time enjoyed Internet access. Nevertheless, the intense public interest and popular participation in Nyerere's obsequies suggests that the official representation 'worked' for many people in the country.

The obliging participation of the private media, including Remmy Ongala whose wide popularity and relative economic security granted him a degree of independence, highlights the ability of CCM officialdom to recruit support from beyond the state sector. For somebody like Ongala, it need not have been merely about politics; his sympathies with Nyerere are consistent with the focus on 'ordinary people' and their troubles in his lyrics. A similar commonality of purpose between officialdom and the private sector, with a slightly more opportunistic bent, is evident also in the background of a 2001 pamphlet on Nyerere's funeral. With Nyerere's portrait superimposed on a scene from his funeral, the inclusive message is: 'Tanzania, we will remember you forever, father of the nation. You have left us [rule of] law, unity, peace, love and cooperation' (Figure 1).

Its author, Michael Mwakilasa, is a businessman who is not directly involved in politics. In a 2009 newspaper profile of his bio-fuel company, he nevertheless stated that 'people should stop blaming the government [for their poverty] but work hard instead. The government should only create an enabling environment for people to realize their full potential' while also acknowledging that 'the Ministry of Energy and Minerals supports me a lot'. ${ }^{25} \mathrm{He}$ thus epitomizes the fact that part of the entrepreneurial middle class, rather than presenting an independent alternative to state actors in the economy, is closely aligned with them. ${ }^{26}$

The voices immediately surrounding Nyerere's death, then, suggest that very diverse sets of people converged around the official representation of Nyerere as the originator of a peaceful political culture and protector of the weak. Yet while this image was supported by a groundswell of popular sympathy and appreciation for the deceased, parts of it were also very carefully put together and put about. Moreover, from the start this narrative contained a number of different overtones - some tending towards the egalitarian, some towards the authoritarian - that permitted very different elaborations of Nyerere's memory.

25. The Sunday Citizen, 10 May 2009, <http://www.thecitizen.co.tz/newo.php?id=12448> (10 September 2012). For Mwakilasa's participation in the Davos Economic Forum, 2010, see <http://www.youtube.com/watch?v=1Ii4BSas_Qk> (18 December 2012).

26. On the rise of the African middle class, see Stephen Ellis, Season of Rains (Hurst and Co., London, 2010). 


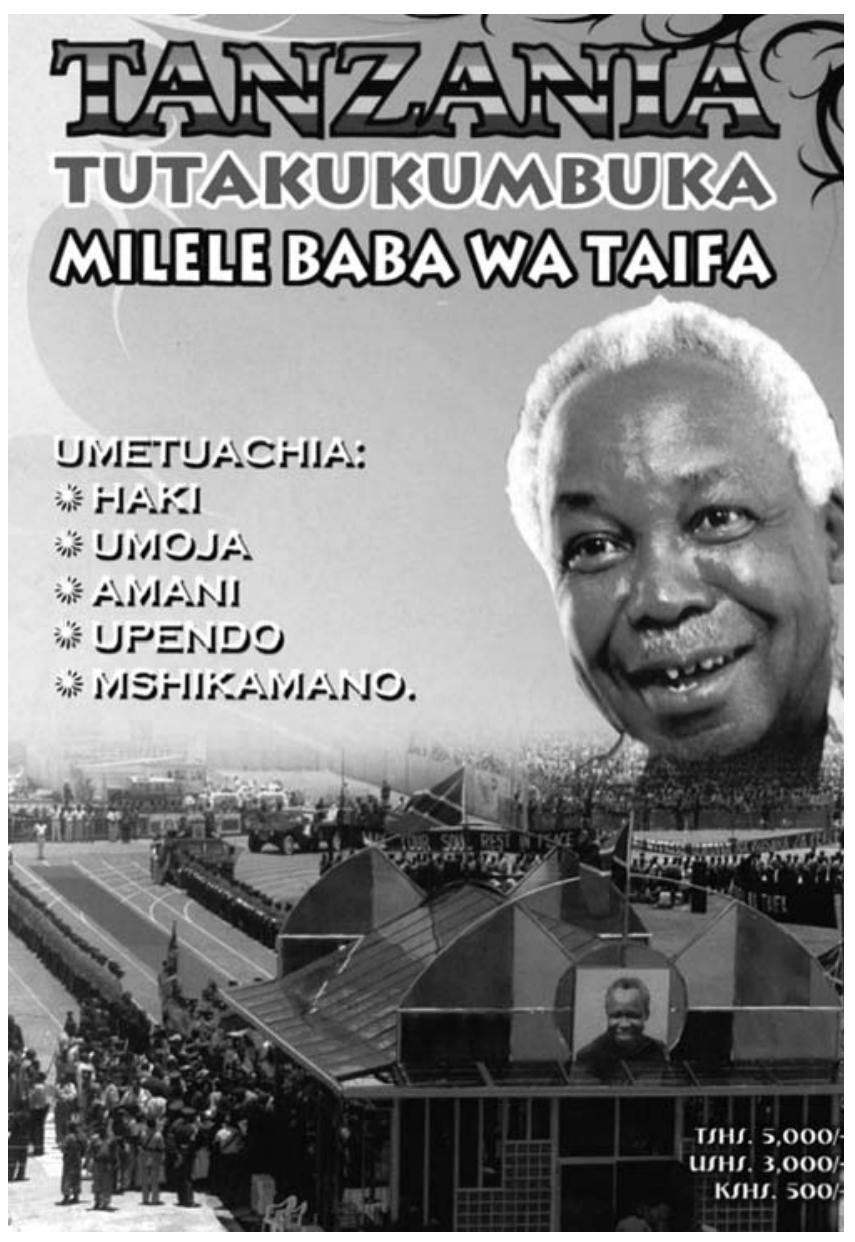

Figure 1. Front cover of Michael Mwakilasa's brochure (see main text for translation). The photograph shows a scene from Nyerere's funeral. With permission of the author.

The limits of official representations: Nyerere the failed despot and Nyerere the advantage-seeker

Meanwhile, very different perspectives on Nyerere are evident in interviews from the rural Lindi region. This part of the country has not done well in the post-colonial period; its main export crop, cashew nuts, has remained economically marginal and its education record is poor. ${ }^{27}$ Here,

27. Berta Koda and Pekka Seppaelae, The Making of a Periphery (Nordiska Afrikainstitutet, Uppsala, 1998). 
the influence of the official representations of Nyerere was clearly felt, yet arguably the most revealing variations in the image of Nyerere were those that could not easily be placed either within or in opposition to the official Nyerere 'paradigm'. Rather, the way that Nyerere was remembered in Lindi revealed provincial people trying to think through his heritage in a way that drew on official representations, but also on different, locally relevant categories, and on first-hand experience with his policies. ${ }^{28}$

Most often, the name Nyerere came up in connection with what were arguably the biggest events in rural Tanzania in the second half of the twentieth century: the independence campaign and villagization. Unsurprisingly, the valency of these two events was very different. Respondents who were young adults in the 1950 s often spoke of that period with palpable nostalgia. ${ }^{29}$ The personal impression Nyerere created touring the country as the leader of the independence campaign was crucial in persuading his audiences that independence was a viable project. ${ }^{30}$

For example, one man who had witnessed a speech by Nyerere in the mid-1950s could still reproduce the content of that speech at some length. ${ }^{31}$ How accurate his recollections are is another question, but they certainly fit with what we know of Nyerere's rhetoric during the period, focusing on the need for the English to 'return the country' to its inhabitants peacefully. Similarly, when discussing the early post-independence period, respondents sometimes made reference to one of Nyerere's catchphrases without even explicitly attributing it to him, saying that Tanzania then was in a state of 'war against three enemies: poverty, illness, and ignorance'.

Besides the war against poverty, illness, and ignorance, though, the best-remembered Nyererean turn of phrase was one that was evoked with a great deal of bitterness: his statement in 1973 that villagization was sio ombi, ni amri, not a request, but an order. In connection with

28. The following passage is based on a number of interviews from Lindi, Mingoyo, and Rwangwa, all in Lindi region, in 2000 and 2003. The most important interviews were: Ibrahim Nassoro Kimbega, Rwangwa-Mchangani, 7 September 2003; Hassan Mchoya, Rwangwa-Nachingwea, 31 October 2003; Issa Makolela, Rwangwa-Likangara, 3 September 2003; Issa Mapua, Rwangwa-Kilimahewa, 2 November 2003; Omari Salum Njalimbo, Rwangwa-Dodoma, 10 October 2003.

29. Generally on this period and the display of political and rhetorical skills delivered by Nyerere, see John Iliffe, 'Breaking the chain of imperialism at its weakest link' in James Giblin and Gregory Maddox (eds), In Search of a Nation: Histories of authority and dissidence in Tanzania (James Currey, Oxford, 2005) pp. 168-97; Susan Geiger, TANU Women: Gender and culture in the making of Tanzanian nationalism, 1955-65 (Heinemann, Portsmouth, NH, 1997).

30. Geiger, TANU Women; Felicitas Becker, Becoming Muslim in Mainland Tanzania (Oxford University Press, Oxford, 2008), Chapter 7. For the politics of this region in the run-up to independence more broadly, see Gus Liebenow, Colonial Rule and Political Development in Tanzania (Northwestern University Press, Evanston, IL, 1971).

31. Interview, Ibrahim Nassoro Kimbega, Rwangwa-Mchangani, 7 September 2003. 
villagization, with their vital interests at stake, villagers remembered judging Nyerere as pragmatically and mistrustfully as they would have a colonial authority figure. Discussing the announcement that villagization had been made compulsory, one villager recalled that they doubted Nyerere's ability to do as he said he would. '[We thought] maybe he is a liar,' was the phrase he used, suggesting a suspicion of large-scale political bluff. $^{32}$ This hope, of course, turned out to be unfounded: villagers recalled a good deal of force involved in the actual move, significant loss of property, and much confusion about their entitlements in the new locations. They also recalled the shortage of basic necessities that resulted, particularly with regard to clothing, and they identified these problems closely with Nyerere, while attributing the 'return' of proper clothing to his successor, Ali Hassan Mwinyi. ${ }^{33}$ There is a sense in these narratives that Nyerere had his chance to improve villagers' lot, and wasted it. One respondent went so far as to characterize the measures taken under Nyerere's reign as ukatili, 'cruelty'. ${ }^{34}$

This is not to say that the image of Nyerere officially extolled in October 1999 was absent among these interviewees. Villagers did praise Tanzania's peace and stability and occasionally identified it as a Nyererean heritage. Moreover, it was noticeable that a somewhat excessive number of male informants born early in the inter-war period (but typically unsure of their exact date of birth) claimed to have been born in 1922, the year of Nyerere's birth (as widely publicized at the time of his death). If it is true that imitation is the sincerest form of flattery, this can be taken as a compliment these men paid their deceased President. Put differently, they did implicitly endorse Nyerere as a 'model patriarch' by seeking to be like him.

Yet rural respondents also made claims about Nyerere that are not so much praising or damning, as just attempts to make sense of the man in his time, with reference to the respondents' own priorities. One even

32. Interview, Omari Salum Njalimbo, Rwangwa-Dodoma 10 October 2003. The informant's insistence, nearly universal among his peers, that while many people were forced to move he was not one of them, indicates that having arrived as a victim of forced removal may affect a person's status or entitlements even in the present. But 'villagizees' could also assert a significant degree of influence over local micro-politics, thanks to the electoral elements in the constitution of ujamaa villages. In Rwangwa, it was widely acknowledged that Issa Makolela had been voted out of his local party office shortly after villagization. See also Achim von Oppen, 'Villages beyond ujamaa: land conflict and ecology in western Handeni' in Doris Schmied (ed.), Changing Rural Structures in Tanzania (LIT Verlag, Münster, 1996), pp. 85-106; Donald Vaughn Hassett, Economic Organisation and Political Change in a Village of South East Tanzania (University of Cambridge, unpublished PhD thesis, 1984).

33. Elaborated by Issa Makolela, and Hassan Mchoya in the above-mentioned interviews; Hyden also discusses this crisis in Beyond Ujamaa.

34. For the denigration of 'idle' urban youth, not only during villagization, see Andrew Ivaska, Cultured States: Youth, gender and modern styles in 1960s Dar es Salaam (Duke University Press, Durham, NC, 2011). 
made Nyerere the patron of policies he rejected, such as active discrimination against South Asians. ${ }^{35}$ Overall, these reminiscences amount in part to quite plain stories of political experimentation and eventual failure. The kind of lionization that occurs in Nyerere's funeral songs is conspicuous by its absence. Nor do villagers paint Nyerere as a patron or patriarch; there is a sense of his having been, once in power, quite distant. This historical Nyerere is much less rhetorically useful than the official version, and is better described as the product of an effort to make sense of a history of post-colonial failures.

A different pattern of dissent was produced by the younger, entrepreneurial generation that has little time for the moralist execration of 'selfseeking' profit-oriented business that was part of Nyererean rhetoric. While Nyerere was lying in state, a businessman - perhaps forty years old, in an impeccable suit - joined my table at a central Dar es Salaam restaurant. His aim, it turned out, was to obtain more information about Nyerere's medical treatment in Europe. What he wanted to hear was that the hospital where Nyerere had died was private, and expensive. Knowing St Thomas's hospital to be an NHS facility, I contradicted him, although I had wondered, considering that Nyerere had no known immigration status in Britain, whether his country or the former colonial 'mother country' was paying for his treatment. My interlocutor remained sceptical. Identifying himself as an entrepreneur, and from an ethnic group he characterized as well-travelled and full of business sense (the Manyema), he insisted that it was impossible for a man like Nyerere to have relied on public facilities.

The man's demeanour, appearance, and opinions identified him as one of a growing stratum of African businessmen who have no time for the communalist rhetoric and criticism of capitalism that Nyerere is known for. He was one of many in his and subsequent age groups that dream of going abroad to do business degrees, rather than to study agricultural or construction engineering like an earlier generation. They endorse wealth creation through private enterprise, rather than state-directed collective effort in agricultural and infrastructure projects, as the path to progress, and could be called the 'post-SAP' or 'IMF' generation. ${ }^{36}$ As Michael Mwakilasa's example shows, they do not therefore have to be either critical of or fully independent from government, but their memories of Nyerere reveal that they often hold divergent opinions that are not readily traceable in the media.

35. Interview, Omari Salim Njalimbo.

36. See Ellis, Season of Rains; for rural manifestations of the rush into business, see the work of the DARE project on de-agrarianization and rural employment, in particular Deborah Bryceson, 'Sub-Saharan Africa betwixt and between: rural livelihood practices and policies' (ASC Working Papers 43, Leiden, 1999), available online at <https://openaccess.leidenuniv.nl/ bitstream/handle/1887/12912/ASC-075287668-022-01. pdf?sequence=2> (11 January 2013). 
This businessman's suggestion that Nyerere himself had gone for private treatment implied that the old leader himself no longer took the communalist rhetoric of progress that had been characteristic of ujamaa seriously. My interlocutor expressed a cynicism - representative of some Tanzanians' assessment of the state of their country - that converges with well-known Western media coverage about African politics, which tends to see politicians as only ever working for their own advantage, with the rest of the citizenry forced to be equally self-interested if they are to escape the poverty in which politicians' actions trap them. Another expression of this more cynical current at the time of Nyerere's death was speculation about the wealth that his family might have amassed, and how it would now be divided. I encountered it both in 'my' household and in the street.

From the time of Nyerere's death, then, Tanzanians with very different backgrounds retained memories and elaborated views of Nyerere the politician that were strongly at variance with the official paradigm of the 'father of the nation'. It would, of course, have been difficult for CCM to shut down such personal views and recollections. It was also unnecessary so long as the holders of these views did not publicly assert them. Nevertheless, these counter-narratives offer a glimpse of the diversity of political experiences and attitudes in Tanzania that voters' habit of backing the CCM at election time obscures.

\section{Competing uses of the official paradigm}

There has also been a great deal of variation in the way in which endorsements of Nyerere's official memory have been deployed, indicating further layers of political diversity and disagreement. On one hand, the way Nyerere's name has come up in government rhetoric in recent years makes it clear that the effort to use him to legitimize CCM rule continues. Both Benjamin Mkapa, President at the time of his death, and Mkapa's successor Jakaya Kikwete have explicitly invoked his heritage, the latter claiming to build his presidency on 'Nyerere's values'. ${ }^{37}$ Even the Ugandan President Yoweri Museveni, who began his career as a guerrilla fighter, has been quoted as endorsing the official Nyerere in the company of Tanzanian politicians, describing him as 'blessed with extraordinary wisdom and compassion for the oppressed'. ${ }^{38}$ In 2004, the commemoration of Nyerere

37. Southern African News Features, 21 December 2005, 'Tanzania: President Kikwete to build on Nyerere values and Mkapa economics', <http://allafrica.com/stories/200512210002. html> (23 August 2011).

38. The New Sudan Vision, 2 June 2009, 'Tanzania: Nyerere fit to be a saint - Museveni'. 
was enshrined in law. ${ }^{39}$ The party's college for further education and political studies in Dar es Salaam has been renamed the 'Nyerere Academy'. In 2008, nine years after Nyerere's death, CCM officials chose to hold a national meeting at Butiaba, Nyerere's home village and burial site; in 2009 Mwakilasa's pamphlet on Nyerere's funeral was re-issued. ${ }^{40}$

On the other hand, there is also political criticism that takes place within the 'Nyerere as patron [of the poor; of Tanzania]' paradigm. A couple of years after Nyerere's death, a group of striking workers, in the course of a dispute over the privatization of their company, occupied their manager's office singing songs in praise of Nyerere. ${ }^{41}$ In the last general election campaign in October 2010, the leader of Chama cha Demokrasia na Maendeleo (CHADEMA), one of the largest opposition parties, invoked Nyerere against what he characterized as the incumbent's attempts to attract votes with promises of material rewards. He also accused Kikwete of lacking commitment to ensuring that the country's resources were used in the interest of its people - deploying a classic Nyerere policy of economic nationalism to critique the CCM. ${ }^{42}$ These actions make it clear that the proposition of Nyerere, champion of the downtrodden, leaves open the question of who the poor have to be defended against: the official interpretation of Nyerere can be turned against CCM grandees.

The continuing utility of Nyerere for government critics is observable in the pages of the independent weekly newspaper Raia Mwema ('Good Citizen'), published since 2007. Photographs and quotations of Nyerere show up in this periodical at least once a month. In the issue published on 5 December 2007 a photo of Nyerere with the title: 'The first chairman of CCM, Mwalimu Nyerere, was a great defender of the rights of the weakest' ('Mtetezi mkubwa wa haki kwa wanyonge') accompanied an article criticizing CCM's current generation of leaders for paying insufficient attention to the wanyonge. In the 26 March 2008 issue, to complement the CCM's meeting in Butiaba, a headline declared that 'Even in his grave, Nyerere still pities us Tanzanians [if the party does not take steps on high-level corruption]'. The 6 October 2010 issue accompanied an opinion piece with a quotation by Nyerere condemning wealth acquired by theft of common goods.

39. United Republic of Tanzania, The Founders of the Nation (Honoring Procedures) Act, 2004 (Tanzania Government Printer, Dar es Salaam, 2005).

40. Raia Mwema, 26 March-1 April 2008.

41. Timothy Kelsall, 'Governance, democracy and recent political struggles in mainland Tanzania', Fournal of Commonwealth and Comparative Politics 41, 2 (2003), pp. 55-82.

42. Raia Mwema, 'Slaa uses Nyerere to finish off Kikwete' ['Slaa amtumia Nyerere kummaliza Kikwete'], 6-12 October 2012, pp. 1, 3. 


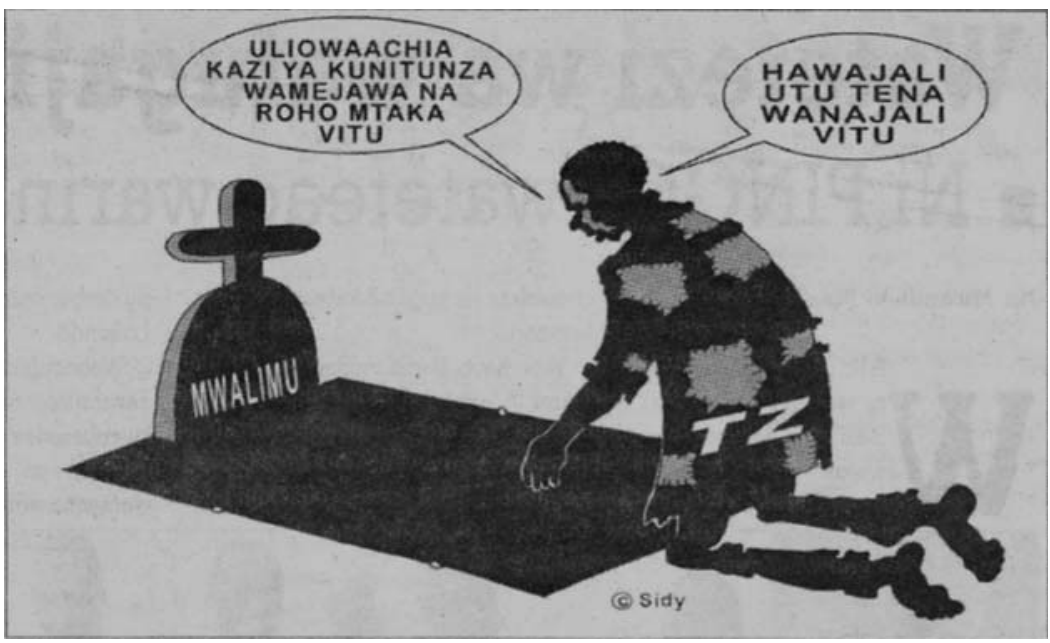

Figure 2. Cartoon from the weekly newspaper Mwana Halisi, May 2012 (see main text for translation). With permission of the publisher.

Many of the mentions of Nyerere are connected to what Tanzanians have come to call ufisadi, 'high-level corruption', reiterating his role as a paragon of virtue in public office. ${ }^{43}$ The type of concerns that Nyerere is evoked to address are well summarized in a cartoon published in another independent weekly paper, Mwana Halisi ('The genuine child') in May 2012. A barefoot, ragged figure representing Tanzania kneels at Nyerere's grave, saying 'Those to whom you have left the task of looking after me have been filled with the spirit of wanting things. They no longer care about humanity; they care about objects' (Figure 2).

This sentiment is widely expressed in present-day Tanzania, as Swahili-speaking visitors to the country will recognize. It corresponds to the mistrust lavished on the wealthy in popular discourse. In recent years, it has been elaborated in the context of the moral anxieties surrounding the slayings of albinos for medicine that proliferated in the late 2000s. Perpetrators, experts, and ordinary observers agreed that the use of these medicines was to obtain wealth, especially through gold digging. ${ }^{44}$ Elsewhere in the country, the 2000s saw renewed anxieties over allegations that some newly wealthy Tanzanians had transformed the recently deceased into zombies - undead quasi-slaves - through witchcraft. These

43. This term has come into its own in the last decade. It establishes corruption in high places as distinct from rushwa, corruption in general.

44. See BBC News Online, 'Tanzania fear over albino killing', 17 December 2007, <http: //news.bbc.co.uk/1/hi/world/africa/7148673.stm> (23 August 2012). 
rumours offered an unflattering explanation for the wealth of those who, in the minds of their neighbours, had not deserved their good fortune. ${ }^{45}$ Four years after Nyerere's death, one of the most popular pop songs in Tanzania in summer 2003 started with the line 'Machozi ya mnyonge, malipo kwa mungu': 'The tears of the downtrodden have their payment with God' ${ }^{46} \mathrm{It}$ was widely thought to refer to the performers' trouble with immigration authorities, casting these officials in the role of oppressors.

Nevertheless, the widespread criticism of $u$ fisadi and rampant materialism in the political class takes on a slightly paradoxical character when one considers that the Tanzanian state remains the main purveyor of essential services in infrastructure, health and education, and the main focus of requests for assistance with developmental or self-help projects. ${ }^{47}$ That this is taken for granted is evident in the cartoon just discussed, where the pauper who represents Tanzania describes the errant officials as charged with 'looking after' her or him. The state continues to ascribe to itself a leading role in development, even if in keeping with international pro-private-sector orthodoxies it casts itself in the role of the 'enabler' rather than planner. Jakaya Kikwete, the current President, came to power on the slogan 'Maisha bora kwa wote', 'A better life for everyone', and the words continue to be quoted, if often by way of complaint. If the state is a poor patron, it nevertheless remains the go-to one for many Tanzanians.

In a way, then, the persistence of Nyerere's influence in Tanzanian political discourse is rooted in the dilemmas faced by a government and citizenry who need each other; who have expectations of each other but struggle to have them met. So far as the government is concerned, perceptive observers of popular politics in Tanzania over the years have come away with the conclusion that - with the exception of the period of villagization - politicians put a significant amount of effort into consensus building. ${ }^{48}$ After all, political quiescence has never been total; violent incidents of protest have occurred sporadically throughout Tanzania's post-colonial history. During villagization, a villager killed an overbearing

45. On witchcraft fears as a critique of iniquitous wealth, see Henrietta Moore and Todd Saunders, Magical Interpretations, Material Realities: Modernity, witchcraft and the occult in postcolonial Africa (Routledge, London, 2001).

46. Baba (father), in these colloquial rhymes serves as a familiar and friendly way of addressing a male listener, not necessarily much older than the speaker.

47. On the official role of the government in development planning see also Africa Development Bank/Africa Development Fund, 'United Republic of Tanzania: country strategy paper 2011-15' (Africa Development Bank, Tunis-Belvedère, June 2011).

48. For the period to 1978 see John Iliffe, A Modern History of Tanganyika (Cambridge University Press, Cambridge, 1979); for the period leading up to villagization see Michael Jennings, 'We must walk while others run: popular participation and development crisis in Tanzania, 1961-69', Fournal of Modern African Studies 41, 2 (2003), pp. 163-87, for the independence era see Hyden, Beyond Ujamaa. 
official. ${ }^{49}$ In the last two decades, there have been occasional violent confrontations with authorities in the countryside, especially over their interference with witchcraft cleansing and over taxation. ${ }^{50}$ Aili Mari Tripp likewise demonstrates the salience of small-scale dissent and negotiation in the urban environment, with recurring confrontations over licensing, transport, and taxation. ${ }^{51}$

While this clashes with images of African politics as unabashedly authoritarian, it is not really surprising. Otherwise marginal people matter as producers and taxpayers, and the most effective way for them to frustrate officials involves tax evasion and refusal to grow the cash crops earmarked for government-controlled marketing. Both of these strategies of noncompliance have been an ongoing headache for post-colonial governments as for their colonial predecessors. ${ }^{52}$ As regards cash cropping, peasants respond to the state's manipulation of producer prices by shifting from cash crops destined for marketing boards and world markets to much less tightly controlled production of foodstuffs for Tanzanian urban markets. ${ }^{53}$ Against this background, the official Nyerere appears as part of an ongoing effort to avoid conflict and cultivate consensus. Underresourced as it is, the state tries to pre-empt confrontations rather than win them, and uses persuasion as an alternative to outright 'buying' of consent through provision of services.

For non-elite Tanzanians, in turn, the 'the state won't help us/let's ask the state for help' trope reflects their unpredictable experiences with public services and the various levels of government they encounter. That this ambivalence is of long standing can be observed by consulting Tripp's account of the conflicting attitudes of different arms of government to the licensing of petty trading and the so-called 'development levy' in the 1980s and 1990s. While party militia harassed petty traders, its 'ten-cell leaders', the lowest level of the party leadership, often sympathized with them. Whether your stall was demolished or survived, then, depended partly on who got there first. ${ }^{54}$ Yet the very name of the hated tax symbolized the government's insistence that it would play a leading role in the development of the country.

Similarly, throughout the 2000s, the ongoing 'Local Government Reform Programme' made a series of promises concerning the accessibility,

49. Hyden, Beyond Ujamaa, p. 102.

50. Tim Kelsall, 'Governance, local politics and districtization in Tanzania: the 1998 Arumeru tax revolt', African Affairs 99, 397 (2000), pp. 533-51; Stacey Langwick, Devils and Development (University of North Carolina, Chapel Hill, unpublished $\mathrm{PhD}$ thesis, 2001).

51. Tripp, Changing the Rules, Chapter 6.

52. Andrew Burton, "The eye of authority: "native" taxation, colonial governance and resistance in inter-war Tanganyika', Fournal of Eastern African Studies 2, 1 (2008) pp. 74-94.

53. Hassett, 'Economic organisation'.

54. Tripp, Changing the Rules, Chapter 6. 
responsiveness, and transparency of local government, and encouraged reporting of small-scale corruption (rushwa). ${ }^{55}$ Through the serikali ya mitaa ('town quarter government') and serikali ya kijiji ('village government'), the state is indeed close to its citizens. ${ }^{56}$ By the same token, local government officials are themselves members of local networks. They may have vested interests in local conflicts over resources such as land, are susceptible to pressure from local communities, and even where they act according to disinterested judgment, may not be seen to be doing so by others. Thus some complaints of malpractice are spurious, some serious, and which ones get heard depends very much on who makes them and to whom. ${ }^{57}$ But it is at least possible to try and get local government to respond.

Meanwhile, as Claire Mercer has shown, the Tanzanian government has done a very good job of appearing consultative in the implementation of the economic 'advice' on poverty reduction proffered by its international donors. ${ }^{58}$ In the process, it again made noises about its continuing role in poverty reduction, while some of the more articulate 'civil society organizations' consulted have asserted that the actual consultations, via workshops, were desultory. Moreover, the surfeit of overlapping poverty-reduction plans they produced was more distracting than informative, as the government ultimately just picked its preferred version with an eye to the international reaction rather than that of internal 'stakeholders'. In this case, the government succeeded in persuading international observers of its good intentions despite internal criticism.

A scandal that erupted in the middle of 2012, meanwhile, illustrates the lack of predictability in the field of civil liberties rather than service provision, though ultimately salaries were at stake. On 25 June, the leader of a doctors' strike at the National Hospital in Dar es Salaam, Dr Ulimboka, was abducted. He was severely beaten, had his teeth and nails pulled out, and was dumped in a forest near the capital. When he was found, surprisingly still alive, the government flew him to South Africa for medical treatment at public expense; the President went on TV to condemn the

55. United Republic of Tanzania, Prime Minister's Office, Local Government Reform Programme II (Decentralisation by Devolution): Vision, goals and strategy, Fuly 2009-Fune 2014 (Government Printer, Dar es Salaam, 2009).

56. These local government institutions arguably constitute an under-researched legacy of ujamaa and villagization; see also footnote 26. For a rare exception see Elke Grawert, Departures From Post-Colonial Authoritarianism (Peter Lang Verlag, Berlin, 2009).

57. Felicitas Becker, "Bad governance" and the persistence of alternative political arenas: a study of a Tanzanian region' in Giorgio Blundo and Pierre-Yves Le Meur (eds), The Governance of Daily Life in Africa (Brill, Leiden, 2009), pp. 73-100.

58. Claire Mercer, 'Performing partnership: civil society and the illusions of good governance in Tanzania', Political Geography 22, 7 (2003), pp. 741-63. 
incident and assert that the government was not in the business of torture and intimidation. ${ }^{59}$

A month later, the paper Mwana Halisi published an article with detailed evidence from telephone records and from the victim, alleging that the abduction was the work of a security official working out of State House. At the same time, it rubbished the case against a Kenyan said by the police to have confessed to the crime, quoting the pastor to whom he was supposed to have confessed as saying no such thing had happened. ${ }^{60}$ The government's reaction was to shut down Mwana Halisi and put the incriminated security officer in a 'safe location'. Several other papers, including Raia Mwema, strongly condemned its closure and stayed open. ${ }^{61}$ Meanwhile, the government opposed a teachers' strike then ongoing in court, but its leaders remained safe.

If Mwana Halisi was right (and its account is certainly more plausible than the idea of a lone Kenyan assailant) the attack on Ulimboka stands out as an ultimately demonstrative, rather than irrational, spike in violence by a government that otherwise stuck to more legalistic methods of repression. Mwana Halisi's punishment, again, appears symbolic, though it is not clear from the vociferous response of the press if the message came across. ${ }^{62}$ Unsurprisingly, one point made in the media in connection with this scandal is that the current leadership's failure to prevent Dr Ulimboka's abduction falls short of the example set by Nyerere. Indeed, they quoted the victim's father to this effect. ${ }^{63}$

On one hand, this invocation of Nyerere appears formulaic: the founding President seems to get dragged into most political disagreements. On the other, although it is contested, the 'official' take on Nyerere nevertheless serves to affirm shared principles in the political arena, as all sides roughly agree on what virtues he stood for, while disagreeing on who embodies them in the present. The influence that these principles have held

59. An image of Ulimboka before receiving treatment can be found at <http://sophiakessy. blogspot.co.uk/2012_06_01_archive.html> (25 December 2012). For the government's denial of a role in his torture, see BBC News Online, 'Tanzania's Jakaya Kikwete denies Steven Ulimboka "torture"', 2 July 2012, <http://www.bbc.co.uk/news/world-africa18671315> (10 September 2012) and the Mwana Halisi article discussed below.

60. At the time of writing, the article was still available online: Mwana Halisi, 'Aliyemteka ulimboka huyo hapa', 25 July 2012, <http://www.mwanahalisi.co.tz/node/2968> (5 September 2012).

61. See Raia Mwema, 1 August 2012, front page and p. 4; Sani, 28 July 2012, front page, and Mseto (normally a sports paper), 1 August 2012 (all bought and read in Dar es Salaam). 62. It is also worth noting that if security officials operating out of State House acted without the President's knowledge, this indicates behind-the-scenes disunity on the forms of repression to use against strikers, and an uncertain future for workers' rights and civil liberties depending on who wins the debate.

63. Mwananchi ('Citizen'), 'Baba yake Dk Ulimboka atoa ya moyoni', 3 September 2012, <http:/www.mwananchi.co.tz/habari/49-uchaguzi-mkuu/26041-baba-yake-dk-ulimboka-atoaya-moyoni> (10 September 2012). 
and will hold over the actions of those in power is debatable, but at the very least politicians have to work around them and, as with Ulimboka, risk being shown up as hypocrites. Again, that will be small consolation for victims of repression. But the diverse uses of Nyerere make a prism that helps distinguish important shades and nuances in what might otherwise appear to be a monochrome support base for the ruling party. Moreover, it suggests that the CCM's hold on power has been harder won, and is more contingent, than is immediately evident.

\section{Conclusion}

The challenges to and divergent uses of Nyerere's official image trace out greater liveliness and diversity in Tanzania's political discourse than CCM's towering electoral dominance suggests. Villagers' memories retain Nyerere the autocrat and some entrepreneurs who are distant from government construe him as corrupt. But even among people who agree on his status as a benign patriarch, the government has not succeeded in shutting down dissent; rather, the 'official' Nyerere constantly serves to hold government to its promises. Too poor and dependent on international donors' goodwill to sustain repression even if they preferred to, the CCM's grandees turn to repression and consensus building in turn. The outcome is a contradictory, hence unpredictable, yet viable political practice that could be characterized as 'consultative authoritarianism'.

Tanzanians' criticisms of their government, as expressed with reference to Nyerere, are clearly reminiscent of the concepts of 'economy of affection' or 'moral economy' that have been used to interpret longstanding political reasoning in East Africa. They also sit well with the concept of the 'zero-sum universe', where one person gets richer only by making others poorer, that has been described as characteristic of peasants' world views. ${ }^{64}$ Yet rather than the bewilderment of people who try to explain their disappointed expectations in anachronistic political categories, the discussion of the failings of the state, which the image of Nyerere helps to focus, expresses current experiences and struggles. Official rhetoric itself constantly draws on the 'idiom of kinship' with reference to Nyerere, but cannot thereby shut down dissent, and the invocation of kinship mingles freely with good government-type donor speak.

The situation is faintly reminiscent of what Jonathon Glassman has described for late pre-colonial towns on the Swahili coast. Then, both patricians and plebeians used the same language of Arabicate civilization and patronage to make claims about entitlement and belonging, but

64. Ralph Austen, 'The moral economy of witchcraft' in John and Jean Comaroff (eds), Modernity and its Malcontents (Chicago University Press, Chicago, IL, 1993), pp. 89-110. 
fought over the definition of its terms and the mutual obligations of patron and client. ${ }^{65}$ Now, again, there is a lot of overlap in what government agents and their critics say the state should be doing, but disagreement over how and to what extent these obligations are fulfilled. Like references to coastal civilization, then, the evocation of Nyerere as a reference point in political conversation can imply very different things for different speakers and listeners, even if the terms of praise are almost identical. His memory continues to elicit contradictory assessments and expectations of the Tanzanian state, whose coexistence reflects a real mixture of strength and weakness.

There are, moreover, also quite different ways of deriving the claims pegged on Nyerere, and the ways they are made, by examining the structure and practices of formal, parliamentary, and government politics. First, the ability of the CCM apparatus to limit and manage internal competition and conflict has been commented on since the early independence period. ${ }^{66}$ Though it remains to be fully understood, it is explained partly by the rules of party and government that mean local officials are often deployed beyond their area of origin and shifted regularly, limiting their ability to build regional power bases. The relative economic weakness of many regions also contributes to keeping the central seats of power in Dar es Salaam and Dodoma the dominant arenas of political competition.

The 'unevenness' of the Tanzanian state over both small and large distances, moreover, need not be seen as a sign simply of weakness. Rather, it can be said to represent the outcome of efforts to manage this weakness. Catherine Boone has demonstrated that separate political compromises with different regions have remained an essential political stratagem for independent African states. ${ }^{67}$ At a local level, the lack of impartiality and predictability among agents of the state is the flip side of central government success in recruiting representatives from among existing local networks, even if these agents then alternate somewhat awkwardly between being 'of the government' and being 'of the village/quarter'. If Nyerere serves as a re-fashioned 'big man', he also represents a rather modern tradition.

Finally, the different discursive incarnations of Nyerere in contemporary Tanzania offer a fresh perspective also on a phenomenon that has sometimes vexed observers of the country: the persistence of 'Nyerere-philia' in both the Tanzanian and the academic public. In part, it can be put down

65. Jonathon Glassman, Feasts and Riot: Revelry, rebellion and popular consciousness on the Swahili coast, 1856-88 (James Currey, Oxford, 1995).

66. Henry Bienen, Tanzania: Party transformation and economic development (Princeton University Press, Princeton, NJ, 1967), Chapter 3, especially p. 80.

67. Boone, Political Typographies. 
to the success of Nyerere's propaganda, not only about himself but also about the sort of society (egalitarian and protective of the weak) that he wanted Tanzania to be. ${ }^{68}$ Yet lionizations of Nyerere survive so well, arguably, also because for the Tanzanian public (and perhaps also for academics) they are not simply or even predominantly about Nyerere. ${ }^{69}$ Rather, Nyerere serves as a reference point for debates over participation, privilege, and entitlement. Much of the fondness for Nyerere in Tanzania is genuine, but it is so precisely because it is not simply about the man, but about what he can be made to stand for.

68. See Jim Brennan, 'Blood enemies: exploitation and urban citizenship in the nationalist political thought of Tanzania, 1958-75', fournal of African History 47, 3 (2006), pp. 389413, for the Nyererean discourse on protection against international exploitation.

69. For an example of some academics' exasperation with Nyerere-philia, see Justin Willis's review of Colin Legum and Geoffrey Mmari's Mwalimu: The influence of Nyerere (Lawrenceville, NJ: Africa World Press, 1995), in African Affairs 95, 380 (1996), pp. 465-66. Western, and not only academic, observers also use Nyerere as a proxy for debates about the kind of moderate left-wing idealism he (or his policies) represented. See Michael Jennings, 'Almost an Oxfam in itself: Oxfam, ujamaa and development in Tanzania in the 1960s and 70s', African Affairs 101, 405 (2002), pp. 509-30. 